\title{
DETERMINATION OF 10 - HYDROXY - 2 - DECENOIC ACID IN ROYAL JELLY BY CAPILLARY ELECTROPHORESIS
}

\author{
ORLANDO MUÑOZ ${ }^{{ }^{*}{ }_{1}}$, SUSANA DECAP ${ }^{l}$, FRANCISCO RUIZ', \\ JOSÉ ARBILDUA2, OCTAVIO MONASTERIO ${ }^{2}$
}

\author{
${ }^{1}$ Departamento de Química, Facultad de Ciencias, Universidad de Chile.Casilla 653 Santiago, Chile \\ ${ }^{2}$ Departamento de Biología, Facultad de Ciencias, Universidad de Chile. Casilla 653 Santiago, Chile
}

(Received: April 21, 2010 - Accepted: March 15, 2011)

\begin{abstract}
Two commercial samples of Royal Jelly sold in Chile, consisting of two imported sample and another sample of known origin obtained freshly harvested from beekeepers were analyzed. The application of capillary electrophoresis (CE) for the separation and determination of the active compound, 10 hydroxy $-2-$ decenoic acid, in Royal Jelly (RJ) in a capillary column with UV detection at $214 \mathrm{~nm}$ is described. In addition, the physicochemical composition of commercial samples was analyzed by determining moisture, ash, lipid and other properties.

The importance of determining the 10-HDA acid lies in the fact that it is the main difference between Royal Jelly and the other bee products, i.e., it is what confers this product its unique characteristics, generating a marked difference. Therefore, a low 10-HDA content implies a low Royal Jelly activity, ascribed to decomposition, poor quality, or something else to the commercialization of a product other than Royal Jelly. This determination was conducted by comparison with a pure 10-HDA standard.
\end{abstract}

Key words: Capillary electrophoresis, 10-hydroxy -2 - decenoic acid, Royal Jelly.

\section{INTRODUCTION}

Royal Jelly (RJ) is a milky-white viscous substance secreted by the hypopharingeal and mandibular glands of nurse worker bees ${ }^{1}$ (Apis mellifera $L$ ) that constitutes the essential food for the larvae of the queen bee'.

The composition of Royal Jelly is quite complex. It contains many proteins, amino acids, organic acids, steroids, esters, phenols, sugar, minerals, vitamins, phyto sterols and other components ${ }^{2}$.

In the market, this product has been sold as a food supplement, known to have many nutrients (vide supra), mainly carbohydrates and lipids, including its characteristic acid, $10 \mathrm{HDA}$, the most important active ingredient in Royal Jelly ${ }^{3,4}$. The content of this acid can be considered as an index for determination of quality ${ }^{5,6}$.

Recent studies have shown that 10 HDA promotes the growth of T-lymphocyte subsets and interleuking -2 , which might suggest that this is a fatty acid and possesses immunoregulation and anticancer activities. It is a beneficial treatment for aging, hypoglycemia and tumors, so $10 \mathrm{HDA}$ is of significant values in medical and health care domains ${ }^{7,8}$. For this reason, the presence of 10-HDA can be used as a marker to differentiate Royal Jelly from other bee products, and the content of 10-HDA has been used as a parameter for Royal Jelly quality ${ }^{9}$.

Based on these effects, many new medicines, health foods and cosmetics containing royal jelly have appeared in recent years. A simple and rapid method for the determination of 10-HDA content is therefore required.

Previous work on the analysis authenticity or the adulteration of RJ is ascertained by the presence of specific carbohydrates or the fatty acid 10 HDA. Additionally, several complementing physical and chemical markers have been proposed to assess its freshness and quality, but these methods suffer from many limitations, and are materials and time consuming, since a number of prior steps are often required to extract the species of interest from the sample matrix and increase potentially interfering compounds ${ }^{10,11}$.

Considering the fact that until now in Chile no regulation exists for RJ quality control, we started studying the chemical composition of Chilean samples of RJ by analyzing their moisture, ash, lipids, and acidity and we concluded that the composition of Chilean RJ shows some differences with respect to other values described in the literature ${ }^{12,13}$.

The aim of this study was to develop a rapid and stable routine method for the determination of 10 - HDA in the only two commercial RJ's sold in Chile and obtain a quality control of the profile of this RJ.

\section{EXPERIMENTAL}

\section{Materials and methods}

\section{Samples and materials}

Two samples of pure RJ were obtained directly from beekeepers in Buin (15 Km southwest of Santiago) and two other's from the commerce in Santiago, Chile, both in May 2006. The first two samples received codes I and II and the samples acquired from the market, codes III and IV. All samples were kept frozen $\left(-40^{\circ} \mathrm{C}\right)$ and protected from light from the reception time until the analysis procedure.

\section{Instrumentation}

A home made capillary electrophoresis system was used. The equipment was built with a Bio-Rad model $1706 \mathrm{UV}-\mathrm{Vis}$ detector, a Spellman high voltage source with an output range of $6-30 \mathrm{KV}$, from High Voltage Electronics Corp., Plainview, NY. The detector was connected to an analog interface, module 406 Beckman System Gold, for the computer storage and analysis of the electropherographic data. Polyimide coated fused silica capillaries, 75 $\mu \mathrm{m}$ internal diameter, were obtained from Beckman Instruments, Inc., USA. A total length of $85 \mathrm{~cm}$ for the capillary and $60 \mathrm{~cm}$ length to the detector were used. UV detection was accomplished with a deuterium lamp at $214 \mathrm{~nm}$. Electrokinetic injection conditions for the samples were $20 \mathrm{~s}$ at $15 \mathrm{KV}$. The separation voltage applied was $20 \mathrm{KV}$.

\section{Sample preparation}

$30 \mathrm{~g}$ of fresh RJ obtained directly from bokeepers were lyophilized, giving $9.51 \mathrm{~g}$ of dry powder. In a typical analysis, a weighed mass of about $0.6 \mathrm{~g}$ Royal Jelly cream sample (commercial capsule) and $0.4 \mathrm{~g}$ lyophilized powder were weighed and dissolved by sonication in separate $50 \mathrm{~mL}$ volumetric flasks with absolute ethanol for one hour. After filtration through a filtering cartridge, with a $0.45 \mathrm{~mm}$ nylon membrane, the samples were put into an ampoule using a disposable syringe set before analysis. The samples were stored at $4{ }^{\circ} \mathrm{C}$ during the analysis.

\section{Reagents}

All solvents used were HPLC grade. Absolute ethanol, analytical reagent grade (Merk); ultrapure water produced by a Milli Q Plus system; Phosphoric acid conc. $85 \%$ Aldrich,. For the standard $10 \mathrm{HDA}$ analysis, a reference standard 
of trans-10-hydroxy-2-decenoic acid acquired from Fine Chemical Prod. Ltd. England; Hydrochloric acid P.A. (Merck). Myristyltrimethylammonium bromide (Aldrich).

\section{Preparation of Standards}

$10 \mathrm{HAD}$ standard working solution $(10 \mathrm{mg}) .10 \mathrm{mg}$ of $10 \mathrm{HDA}$ were poured off accurately into a $10 \mathrm{~mL}$ volumetric flask and diluted to the volume with ultra pure water. The solution was stored at $0{ }^{\circ} \mathrm{C}$

\section{Preparation of Buffer}

$0.98 \mathrm{~g}$ of phosphoric acid were accurately weighed and dissolved in 100 $\mathrm{mL}$ of ultra pure desionized, $\mathrm{CO}_{2}$ free water and adjusted at $\mathrm{pH} 7.2$ with $\mathrm{NaOH}$ and kept at $0^{\circ} \mathrm{C}$.

\section{Electroosmotic flow modifier}

$0.0336 \mathrm{~g}$ of myristyl trimethyl ammonium bromide (MTAB) were dissolved by sonication in $20 \mathrm{~mL}$ of absolute ethanol and the volume was augmented to $100 \mathrm{~mL}$ with ultra pure deionized water $\left(1 \mathrm{mmol} \mathrm{L}^{-1}\right)$ and kept at $0{ }^{\circ} \mathrm{C}$ before use.

\section{Preparation of buffer - flow modifier}

$20 \mathrm{~mL}$ of buffer solution (100 mM phosphate) $40 \mathrm{~mL}$ of electroosmotic flow modifier (MTAB $1 \mathrm{mM}$ ) and $40 \mathrm{ml}$ ultrapure water were added to 100 $\mathrm{mL}$ volumetric flask. The solution was equilibrated at room temperature for one hour and the homogenized solution was $20 \mathrm{mM}$ in buffer and $0.4 \mathrm{mM}$ in MTAB.

\section{Preparation of standards calibration curve}

The following table, shows the concentrations of the standard solutions of $10 \mathrm{HDA}$ and the preparation of the standards.

Table 1. Quantification of 10-HDA. Concentration of the standards for the calibration curve.

\begin{tabular}{|c|c|c|c|}
\hline $\begin{array}{c}\text { Standard } \\
\text { Concentration }\end{array}$ & $\begin{array}{c}\text { Volume of } \\
1000 \mathrm{ppm} \\
\text { Standard }\end{array}$ & $\begin{array}{c}\text { Volume of } \\
\text { Buffer-flow } \\
\text { modifier }\end{array}$ & $\begin{array}{c}\text { Volume } \\
\text { of } \\
\text { Water }\end{array}$ \\
\hline $300 \mathrm{ppm}$ & $150 \mathrm{~mL}$ & $350 \mathrm{~mL}$ & $0 \mathrm{~mL}$ \\
\hline $200 \mathrm{ppm}$ & $100 \mathrm{~mL}$ & $350 \mathrm{~mL}$ & $50 \mathrm{~mL}$ \\
\hline $100 \mathrm{ppm}$ & $50 \mathrm{~mL}$ & $350 \mathrm{~mL}$ & $100 \mathrm{~mL}$ \\
\hline $50 \mathrm{ppm}$ & $25 \mathrm{~mL}$ & $350 \mathrm{~mL}$ & $125 \mathrm{~mL}$ \\
\hline $20 \mathrm{ppm}$ & $10 \mathrm{~mL}$ & $350 \mathrm{~mL}$ & $140 \mathrm{~mL}$ \\
\hline
\end{tabular}

\section{Procedure}

Before each run, the capillary was purged under vacuum with phosphate $20 \mathrm{mM} \mathrm{pH} 7.2$ as a carrier electrolyte, with $0.4 \mathrm{mM}$ MTAB. The electrolyte was prepared fresh at the beginning of each day. The addition of MTAB to the electrolyte reverses the electroosmotic flow, by coating the negative charges of the silica capillaries fused with the positive charges of the quaternary ammonium salt, and also modify the solutes through hydrophobic interactions between the alkyl chain and its hydrophobic moieties; these modifications allow for a fast separation of the anionic species toward the anode.

The standard conditions used for the separation of the analytes of the samples were: $20 \mathrm{~s}$ at $15 \mathrm{KV}$ for electrokinetic injections and $20 \mathrm{KV}$ for running the sample electrophoresis. All the operations were conducted at constant room temperature.

The quantification of 10-HDA was accomplished by a standard calibration curve covering the range from 20 to $300 \mathrm{ppm}$. With the current electrophoretic conditions the 10-HDA showed a migration time $\left(t_{\mathrm{p}}\right)$ of 10.57 min. (Fig.1).

The performance of the separation protocol was characterized by the number of theoretical plates $(\mathrm{N})$ that can be calculated from the peak profiles in the electropherogram ${ }^{16}$, using the formula:

$\mathrm{N}=16(\mathrm{t} / \mathrm{W})^{2} ; \mathrm{W}$ : temporal peak width at the base line. t: migration time of the components.

9500 theoretical plates were obtained for 10-HDA under the current electrophoretic protocol.

Quality Control Methods.

Considering the fact that in Chile there is no regulation for RJ quality control, we started the study of the chemical composition according to a Mexican specification and their test methods, analyzing moisture, $\mathrm{pH}$ and acidity ${ }^{14,15}$. Physicochemical analyses cited in the Mexican RJ regulation were used as follows: titrimetric method for free acidity; gravimetric method for ash content; and potenciometric methods for $\mathrm{pH}^{14,15}$.

The analysis of the samples were made in three replications and the results were expressed as mean value \pm standard error. The correlation between the variables was calculated using analysis of variance (ANOVA test). The criterion for statical significance was $\rho \leq 0.05$.

\section{RESULTS AND DISCUSSION}

Calculation: The 10-HDA content in the sample was assessed using the equation, described by Bloodworth ${ }^{4}$.

\section{0 -HAD in the sample $(\%)=[(\mathrm{C} * \mathrm{~V} * \mathrm{~F}) / \mathrm{W}] * 100$}

Where, $\mathrm{C}=$ concentration of $10-\mathrm{HDA}$ in final solution $(\mathrm{mg} / \mathrm{mL}) ; \mathrm{V}=$ volume of final solution $(\mathrm{mL}) ; \mathrm{F}=$ dilution factor; and $\mathrm{W}=$ weight of sample $(\mathrm{mg})$.

For the limit of detection (LD) and quantification (LC), the following relations were used:

$\mathrm{LD}=3 \mathrm{Sb} / \mathrm{m} ; \mathrm{LC}=10 \mathrm{Sb} / \mathrm{m}$, where $\mathrm{Sb}$ was the standard deviation from the calibration curve and $\mathrm{M}$ the slope of the curve $\mathrm{e}^{4}$.

The results comparing all physicochemical analyses of samples are summarized in tables 2 and 3 .

Table 2. Results from physicochemical analyses of lyophilized commercial samples of Royal Jelly.

\begin{tabular}{|c|c|c|c|c|}
\hline Samples & $\begin{array}{c}\text { Moisture } \\
(\%)\end{array}$ & Ash & $\mathrm{pH}$ & $\begin{array}{c}\text { Free acidity } \\
(\mathrm{meq} / \mathrm{kg})\end{array}$ \\
\hline I & 3.2 & 0.91 & 5.20 & 24.56 \\
\hline II & 2.8 & 0.93 & 5.29 & 12.28 \\
\hline III ( lyophilized ) & 10.1 & 1.01 & 4.37 & 14.59 \\
\hline IV (lyophilized ) & 6.1 & 1.3 & 4.31 & 13.91 \\
\hline
\end{tabular}

Table 3. 10 - HDA content of Royal Jelly samples

\begin{tabular}{|c|c|c|c|c|}
\hline Samples & $\begin{array}{c}10-\mathrm{HAD} \\
(\mathrm{mg} / \mathrm{mL})\end{array}$ & $\begin{array}{c}\text { Final } \\
\text { vol. } \\
(\mathrm{mL})\end{array}$ & $\begin{array}{c}\text { Weight } \\
(\mathrm{mg})\end{array}$ & $\begin{array}{c}\% 10 \\
-\mathrm{HDA}\end{array}$ \\
\hline I & 0.03450 & 20 & 1006.30 & 0.03428 \\
\hline II & 0.01976 & 20 & 1022.42 & 0.01933 \\
\hline III ( lyophilized $)$ & 0.03805 & 3 & 300.64 & 0.01898 \\
\hline
\end{tabular}

The comparison of the values obtained for moisture, $\mathrm{pH}$, ash, free acidity and content of 10-HDA against the Mexican regulation showed that all the results obtained in this work agree with this regulation (table 4), except for the values obtained for the ash of lyophilized Royal Jelly that are lower than the limits recommended.

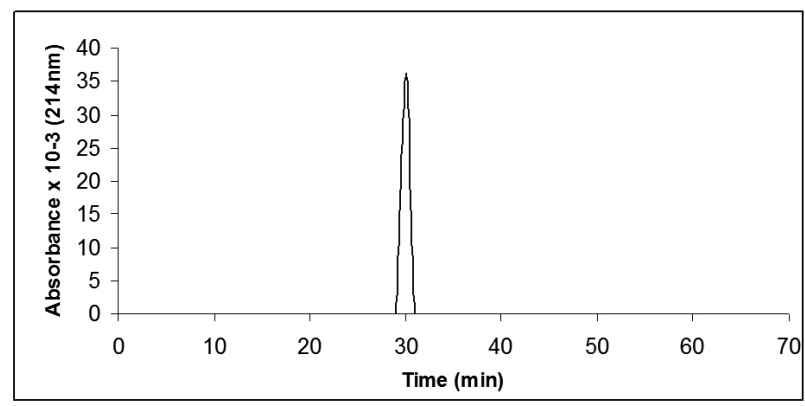

Fig.1 Electropherogram of royal jelly IV 
Table 4. Mean values of the physicochemical analysis of lyophilized Royal Jelly and the values of the Mexican Royal Jelly regulation.

\begin{tabular}{|c|c|c|}
\hline Parameters & Minimum & Maximum \\
\hline $\mathrm{pH}($ Sol.5\%) & 3.4 & 4.5 \\
\hline $10-\mathrm{HDA}$ & & Not less than $1.9 \%$ \\
\hline Ash at $500^{\circ} \mathrm{C}(\%)$ & 2 & 5 \\
\hline Moisture $12 \mathrm{~h}$ at $70^{\circ} \mathrm{C}(\%)$ & 5 & 10 \\
\hline Index acidity $(\mathrm{meq} / 100 \mathrm{~g})$ & 23 & 48 \\
\hline
\end{tabular}

Table 4 shows that the 10-HDA content in samples of commercial and lyophilized RJ was similar to that obtained by Garcia-Almoedo and others ${ }^{12,13}$, but is very low compared with the Mexican regulation ${ }^{14,15}$.

The limit of detection found for the determination of 10-HDA by EC is $12,618 \mathrm{ppm}$, and the limit of quantification is $42.06 \mathrm{ppm}$. The \% values of HDA found in the two lyophilized commercial samples are too low compared with the average \% values of $10-\mathrm{HAD}$ obtained for other Royal Jelly studies described the literature. In general terms, the $\%$ values for pure Royal Jelly are slightly higher than the content in commercial samples.

Finally in this paper we describe a capillary electrophoresis (CE) as a method for the rapid and accurate determination of the main component of the lipidic fractions 10-hydroxy-2- decenoic acid (10-HDA), considered to be the most important active principle ${ }^{17}$. The method is simple, short time analysis and low cost making it an alternative to liquid chromatography.

\section{REFERENCES}

1. G.Lerker, P.Capella, L.S. Conte, F.Ruini, G.Giordani, Lipids, 12, 912, (1981).

2. FAO.Value Added Products from Beckeeping. FAO Agricultural Services Bulletin 124. FAO Rome. Italy. (1996)
3. J.F. Antinelli, S. Zeggane,R. Davico, C.Rognone, J.P.Faucon, \& L.Lizzani. Food Chem., 80, 85, (2003).

4. B.C.Bloodworth, C.S. Harn, C.T. Hock, \& Y.O.Boon, J.AOAC 78, 1019, (1995).

5. S.R. Howe, J. Apic. Res. 24, 561.(1985).

6. L Jia, H X.Zhang, X.L.Kou, \& Z.D.Hu, Chromatographia 41, 605, (1995)

7. J. F. Antinelli, S. Zeggane, R. Davie, C. Rogone, J.P. Faucon, L. Lizzani Food Chemistry 80 (1): 85-89 (2003).

8. N.Hattori, H. Nomoto, H. Fukumitsu, S. Mishima, S. Furukawa Biomedical Research 28, 261-266. (2007).

9. J.Zhou, X.Xue, Y.Li, J.Zhang, \& J.Zhao, J. AOAC Intern. 90, 244,. (2007).

10. D. Vucevic, E. Melliou, S. Vasilijic, S. Basic, P. Ivanovski, I. Chinou, M. Colic Int. Immunopharmacol 7 1211-1220 (2007).

11. G. F. Townsend, W. H. Brown, E. E. Felauer, B. Hazlett Can. J. Biochem. Physiol. 39 1765-1770 (1961).

12. L.H.Garcia Amoedo, \& L.Almeida Muradian, Quim. Nova 30 (2), 257, (2007)

13. L.C.Pamplona, R.Azedo, K.C. Oliveira, L.H.Garcia Amoedo, \& L.Almeida Muradiam. Cienc. Tecnol. Aliment. Campinas 24 (4) 608, (2004).

14. Secretaría de Economía, Estados Unidos Mexicanos Productos Alimenticios No Industrializados Para Consumo Humano Jalea Real Especificación y Métodos de Prueba NMV FF 104. SCFI, 3. (2004 a).

15. Secretaría de Economía, Estados Unidos Mexicanos (2004 b). Productos Alimenticios No Industrializados Para Consumo Humano Jalea Real Especificación y Métodos de Prueba NMV FF 104. SCF1. 4

16. R.Kuhn, \& S.Hoffstetter-Kuhm, Capillary electrophoresis principles and practice. Springer-Verlag, Berlin, Heidelberg (1993).

17. M-S.Blum, A.F.Novak, Taber III (1959).10-hydroxy-D2-decenoic acid, an antibiotic found in royal jelly. Nature 100, 452-453. 